\title{
PERBANDINGAN KONSENTRASI PROGESTERON SELAMA SIKLUS BIRAHI PADA DOMBA WARINGIN YANG DIINDUKSI PGF2 $\alpha$ DAN KOMBINASI PGF2 $\alpha$ DAN GnRH
}

\section{The Comparison of Waringin Sheep Progesterone Level during Estrous Cycle Induced by PGF2 $\alpha$ and Combination of PGF2 $\alpha$ and GnRH}

\author{
Yezi Gita Rahayu, Tongku Nizwan Siregar, Gholib, Cut Nila Thasmi, Herrialfian, Razali Daud, \\ Zuhrawati, Hamdan, Rasmaidar
}

Faculty of Veterinary Medicine, Universitas Syiah Kuala

Teuku Hasan Kreung Kalee No.4, Kopelma Darussalam, Syiah Kuala, Banda Aceh, Aceh 23111

E-mail : siregar@unsyiah.ac.id

\begin{abstract}
This study aimed to compare the progesterone concentrations in Waringin sheep estrus cycle which induced by PGF $2 \alpha$ or the combination of PGF2 $\alpha$ and GnRH. This study used six Waringin sheep those were divided into twice groups, $K 1$ and $K 2 . K 1(n=3)$ were injected by $7.5 \mathrm{mg} P G F 2 \alpha$ intramuscularly for 10 days, while $K 2(n=3)$ were injected by PGF2 $\alpha$ and GnRH. On the first day K2 were injected by $7.5 \mathrm{mg}$ $P G F 2 \alpha$, then followed by injection $50 \mu \mathrm{g}$ of GnRH on day 8th and re-injected by $7.5 \mathrm{mg} P G F 2 \alpha$ on day 15th. On day 18th, sample was re-injected using $50 \mu \mathrm{g}$ GnRH. Waringin sheep those showed estrus symptoms were detected visually and with signs showed by sheep stud. Blood samples were taken on the 7 th, 14th, and 21 st day after the peak heat. The measurement of progesterone concentration was conducted by enzyme linked immunosorbent assay (ELISA). The results showed those the concentrations of progesterone on day $7 \mathrm{th}, 14 \mathrm{th}$, and 21 st on $\mathrm{K} 1$ vs $\mathrm{K} 2$ were $1.324 \pm 1.079,7.607 \pm 8.922$, and $5.220 \pm 1.653$ vs $4.705 \pm 3.369,4.184 \pm 5.512$, and $1.797 \pm 0.898 \mathrm{ng} / \mathrm{mL}(P>0,05)$, respectively. In conclusion, the concentration of progesterone of Waringin sheep after inducing with PGF $2 \alpha$ or combination PGF $2 \alpha$ and GnRH at different cycle periode did not show differences.
\end{abstract}

Keywords: GnRH, PGF2 $\alpha$, Progesterone, Waringin Sheep, Estrus Cycle

\section{PENDAHULUAN}

Domba Waringin merupakan jenis (breed) baru hasil persilangan dari empat jenis domba, yakni domba barbados asal Karibia (Amerika Latin), domba suffolk (Inggris), domba stcroix (Australia), dan domba lokal ekor tipis (Indonesia). Perkembangbiakan domba ini sangat cepat karena bersifat profilik atau beranak 2-4 ekor per kelahiran. Namun, produktivitas domba ini masih belum optimal. Salah satu faktor penyebab belum optimalnya produktivitas adalah sulitnya mendeteksi gejala birahi (Ridwan, 2006). Birahi atau estrus secara fisiologis merupakan masa subur dengan waktu relatif singkat yaitu 3036 jam pada domba dengan waktu ovulasi 12-24 jam sebelum akhir estrus (Blakely dan Bade, 1998). Domba betina dewasa selalu mengalami siklus birahi secara periodik dengan lama satu siklus rata-rata 16-17 hari dalam keadaan tidak bunting (Toliehere, 1985).

Proses reproduksi berkaitan dengan mekanisme sistem hormonal, yaitu hubungan antara hormon-hormon hipotalamus hipofisa yakni Gonadotrophin Releasing Hormone (GnRH), Follicle Stimulating Hormone (FSH) dan Luteinizing Hormone (LH), hormon-hormon ovarium (estrogen dan progesteron), dan hormon uterus (prostaglandin) (Hafez dan Hafez, 2000). Hormon ovarium yang mempunyai peranan besar terhadap reproduksi adalah estrogen dan progesteron.

Menurut Partodiharjo (1992), progesteron adalah nama umum untuk grup steroid yang terdiri dari 21 atom karbon. Progesteron merupakan salah satu hormon penting yang berhubungan dengan reproduksi yang disekresikan oleh sel-sel luteal korpus luteum (Hafez dan Hafez, 2000). Progesteron merupakan hormon reproduksi yang bekerja sinergis dengan estradiol sejak pubertas untuk menstimulasi terjadinya ovulasi dengan jalan menggertak pelepasan LH (Cole dan Cupp, 1969).

Pada domba lokal, konsentrasi progesteron selama periode pembentukan korpus luteum berhubungan dengan jumlah korpus luteum, sedang konsentrasi progesteron pada pertengahan kebuntingan berhubungan dengan jumlah anak 
yang dilahirkan (Siregar, 2002). Konsentrasi progesteron serum darah dapat menentukan keadaan hewan tersebut dalam keadaan infertil, normal, birahi, dan bunting sehingga dapat digunakan untuk deteksi birahi, pemeriksaan kebuntingan, dan mengetahui kondisi patologis lainnya. Untuk meningkatkan efisiensi produksi dan reproduksi pada ternak, maka diperlukan suatu informasi profil hormonal pada siklus birahi. Informasi akurat tentang hormon reproduksi selama masa siklus birahi penting untuk diteliti sebagai konsep dasar proses ovulasi, siklus regresi korpus luteum, kebutuhan hormon untuk manifestasi birahi, kebuntingan, dan kelahiran.

Pada penelitian ini, untuk mengukur konsentrasi progesteron pada domba Waringin, terlebih dahulu mendapat induksi sinkronisasi birahi dengan PGF2 $\alpha$ dan kombinasi PGF2 $\alpha$ dengan GnRH yang populer dengan istilah ovsynch (Taponen, 2009). Metode ovsynch telah dilakukan pada sapi aceh (Efendi et al., 2015). Metode ovsynch mampu meningkatkan angka kebuntingan dibandingkan dengan metode PGF $2 \alpha$ karena kemampuannya meningkatkan konsentrasi progesteron melalui pembentukan korpus luteum asesoris (Pursley et al., 1995), oleh karena itu diduga bahwa konsentrasi progesteron akan lebih tinggi pada domba Waringin yang diinduksi dengan protokol ovsynch atau kombinasi hormon PGF2 $\alpha$ dan GnRH.

\section{MATERI DAN METODE}

Penelitian ini dilaksanakan di peternakan UD. Atjeh Livestock Lamnyong, Darussalam, Banda Aceh dan Laboratorium Riset Fakultas Kedokteran Hewan Universitas Syiah Kuala, Banda Aceh. Sampel penelitian adalah serum darah yang dikoleksi dari enam ekor domba Waringin betina berumur 2 - 3 tahun.

\section{Sinkronisasi estrus}

Domba dibagi dua kelompok perlakuan yaitu K1 $(n=3)$ adalah kelompok yang diinduksi dengan 7,5 mg PGF2 $\alpha$ secara intramuskuler, dua kali injeksi dengan interval 10 hari. K2 $(n=3)$ adalah kelompok yang diinduksi kombinasi PGF2 $\alpha$ dan GnRH. Protokol untuk K2 dimulai pada hari ke-1 dengan injeksi dengan 7,5 mg PGF2 $\alpha$; hari ke- 8 diinjeksi dengan $50 \mu \mathrm{g}$ GnRH dan hari ke-15 diinjeksi kembali dengan 7,5 mg PGF2 $\alpha$; hari ke-18, kambing diinjeksi kembali dengan $50 \mu \mathrm{g}$ GnRH (Simoes, 2016). Pola perlakuan ovsynch disajikan pada Gambar 1.

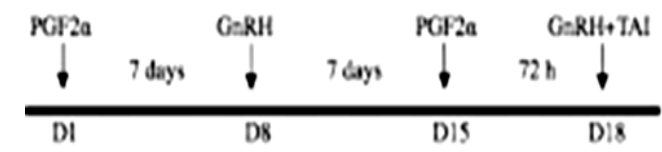

Gambar 1. Pola perlakuan ovsynch pada domba Waringan $(\mathrm{D}=$ hari, $\mathrm{h}=$ jam $)$

Pengamatan birahi dilakukan tiga kali sehari pada pukul 06.00, 12.00, dan 18.00 WIB secara visual dibantu dengan pejantan selama empat hari sejak penyuntikan PGF2 $\alpha$ terakhir.

\section{Pengambilan sampel darah}

Pengambilan sampel darah dilakukan pada hari ke-7, ke-14 dan ke-21 siklus birahi. Sampel darah sebanyak $5 \mathrm{ml}$ diambil dari vena jugularis menggunakan disposible syringe $5 \mathrm{ml}$, kemudian dimasukkan dalam microtube dan ditempatkan dalam termos es. Sampel darah dibawa ke Laboratorium Riset Fakultas Kedokteran Hewan Universitas Syiah Kuala untuk diambil serumnya dengan cara sentrifugasi dengan kecepatan 3.000 rpm selama 15 menit. Serum diambil dari tabung dengan pipet mikro dan dimasukkan dalam microtube, disimpan dalam freezer $-20^{\circ} \mathrm{C}$ sampai dilakukan pengukuran progesteron.

\section{Pengukuran konsentrasi progesteron}

Tiap sumur microplate ELISA dimasukkan $25 \mu$ l larutan standar, sampel, dan kontrol, kemudian ditambahkan $200 \mu \mathrm{l}$ reagen konjugat progesteron pada tiap sumur, selanjutnya diinkubasi selama 60 menit pada suhu ruang. Larutan dibilas sebanyak 3 kali dengan menambahkan larutan pencuci sebanyak $300 \mu \mathrm{l}$ pada setiap sumur. Tiap sumur dimasukkan sebanyak $100 \mu$ l larutan substrat solution dan diinkubasi selama 15 menit pada suhu ruang. Reaksi enzimatik dihentikan dengan menambahkan $50 \mu \mathrm{l}$ stop solution ke tiap sumur. Nilai absorbansi dibaca pada ELISA reader dalam waktu 10 menit setelah ditambahkan stop solution dengan absorbansi $450 \pm 10 \mathrm{~nm}$.

\section{Analisis Data}

Data konsentrasi progesteron domba Waringin pada K1 dan K2 dianalisis menggunakan uji split plot menggunakan program SPSS for windows 16.0.

\section{HASIL DAN PEMBAHASAN}

Konsentrasi progesteron pada domba Waringin selama siklus birahi yaitu hari ke-7, 14, dan 21 hari setelah diinduksi PGF2 $\alpha$ atau kombinasi PGF2 $\alpha$ dan GnRH disajikan pada Tabel 1. Konsentrasi progesteron pada siklus 
birahi domba Waringin pada hari ke-7; $14 ; 21$ masing masing adalah 1,$324 ; 7,607 ; 5,22 \mathrm{ng} / \mathrm{ml}$ dengan induksi PGF2 $\alpha$ dan 4,705; 4,184; 1,797 $\mathrm{ng} / \mathrm{ml}$ pada induksi birahi kombinasi PGF2 $\alpha$ dan $\mathrm{GnRH}$, diketahui bahwa konsentrasi progesteron cenderung berfluktuasi. Fluktuasi konsentrasi progesteron merupakan interpretasi dari aktivitas ovarium yaitu pembentukan maupun regresi korpus luteum (Wijono dan Didi, 1998).

Tabel 1. Konsentrasi hormon progesteron selama siklus birahi pada domba Waringin yang diinduksi PGF2 $\alpha$ atau kombinasi PGF2 $\alpha$ dan GnRH (ng/ml)

\begin{tabular}{lccc}
\hline \multirow{2}{*}{ Perlakuan } & \multicolumn{3}{c}{ Periode (hari) setelah birahi } \\
\cline { 2 - 4 } & 7 & 14 & 21 \\
\hline PGF2 $\alpha($ K1) & $1,324 \pm 1,079^{\mathrm{Aa}}$ & $7,607 \pm 8,922^{\mathrm{Ab}}$ & $5,220 \pm 1,653^{\mathrm{Ab}}$ \\
$\begin{array}{l}\text { Kombinasi PGF2 } \alpha \\
\text { dan GnRH (K2) }\end{array}$ & $4,705 \pm 3,369^{\mathrm{Aa}}$ & $4,184 \pm 5,512^{\mathrm{Aa}}$ & $1,797 \pm 0,898^{\mathrm{Aa}}$ \\
\hline
\end{tabular}

a, b Superskrip yang berbeda pada baris yang sama menunjukkan perbedaan yang nyata $(\mathrm{P}<0,05)$

A,B Superskrip yang berbeda pada kolom yang sama menunjukkan perbedaan yang nyata $(\mathrm{P}<0,05)$

Konsentrasi progesteron domba Waringin pada K1 di hari ke-7 dan ke-14 menunjukkan perbedaan yang nyata $(\mathrm{P}<0,05)$. Konsentrasi progesteron hari ke-7 relatif rendah dan cenderung meningkat pada hari ke-14 siklus birahi. Hal ini terjadi karena hari ke-14 merupakan puncak fase luteal yaitu aktifnya korpus luteum sehingga sekresi progesteron meningkat, sebagai referensi bahwa menurut Siregar (1998) progesteron dalam serum darah kambing kacang tinggi $(2-10 \mathrm{ng} / \mathrm{ml})$ pada hari 812 siklus dan ketika korpus luteum mengalami regresi konsentrasinya menjadi sangat rendah $(<1 \mathrm{ng} / \mathrm{ml})$. Kadar progesteron tertinggi dapat terjadi pada fase bunting dengan perkembangan korpus luteum yang maksimal. Pada saat tidak terjadi kebuntingan atau kandungan tidak terimplantasi embrio, akan diikuti penurunan kadar progesteron secara bertahap yang diakibatkan oleh terjadinya regresi korpus luteum (Wijono dan Didi, 1998).

Konsentrasi progesteron domba Waringin pada K2 di hari ke-7, ke-14 dan ke-21 menunjukkan perbedaan yang tidak nyata $(\mathrm{P}>0,05)$. Hal ini terjadi kemungkinan karena korpus luteum yang tidak berfungsi secara optimal. Jaenuddin dan Hafez (2000) menyatakan bahwa rendahnya konsentrasi progesteron dapat disebabkan ternak mengalami disfungsi ovarium karena progesteron dihasilkan oleh corpus luteum (CL) dan CL ada berada di ovarium, maka rendahnya konsentrasi progesteron adalah penyebab disfungsi ovarium. Gangguan reproduksi berupa tidak berfungsinya ovarium, paling sering disebabkan oleh karena pergantian musim, defisiensi nutrisi, stres akibat laktasi, dan ketuaan (Gracia et al., 1996).

Perlakuan K1 dan K2 tidak menunjukkan perbedaan yang signifikan pada setiap periode koleksi darah $(\mathrm{P}>0,05)$ meskipun terdapat kecenderungan bahwa konsentrasi progesteron domba Waringin pada K1 lebih besar dibandingkan K2. Hal ini berbeda dengan laporan sebelumnya. Mee et al. (1993) menyatakan bahwa sapi yang diinjeksikan dengan GnRH pada saat estrus memiliki konsentrasi progesteron yang lebih besar setelah ovulasi, selama 40 hari setelah pemberian $\mathrm{GnRH}$ sapi dapat mempertahankan kebuntingan karena meningkatnya rasio sel teka pada korpus luteum.

Menurut Arimbawa et al. (2012) peningkatan dan penurunan kadar progesteron sejalan dengan perkembangan korpus luteum selama siklus birahi. Konsentrasi progesteron pada puncak birahi sangat rendah $(0,1 \mathrm{ng} / \mathrm{ml})$ (Thorburn, 1969). Neher et al. (1954) melaporkan bahwa selama siklus birahi konsentrasi progesteron pada domba bervariasi dari 0,3-2 ng/ml dan $6 \mathrm{ng} / \mathrm{ml}$ pada puncak fase luteal. Penurunan konsentrasi progesteron pada domba terjadi setelah hari ke- 14 siklus estrus dan korpus luteum mulai mengalami regresi sebagai akhir dari fase luteal (Thorburn, 1996). Hal ini menjelaskan bahwa setelah hari ke- 14 mulai dilepaskan agen luteolitik yang dapat meregresikan korpus luteum.

Nilai standar deviasi yang diperoleh kelompok perlakuan $\mathrm{K} 1$ dan $\mathrm{K} 2$ sangat tinggi pada hari ke-14. Hal tersebut mungkin terjadi karena jumlah ovulasi yang berbeda pada setiap individu, walaupun berada pada status reproduksi yang sama. Domba pada umumnya bersifat prolifik dengan jumlah anak satu sampai empat ekor per induk untuk setiap kelahiran (Sumaryadi et al., 2001). Jumlah anak yang dilahirkan berhubungan erat dengan jumlah ovulasi (Bradford, 1985; Bradford et al.. 1986; Manalu et al., 1994). Folikel yang telah 
mengalami ovulasi akan membentuk korpus luteum. Jumlah korpus luteum berkaitan erat dengan konsentrasi progesteron (Wubishet et al.,1991).

Konsentrasi progesteron $\mathrm{K} 1$ dan $\mathrm{K} 2$ pada hari ke-7 adalah 1,324 ng/ml dan 4,705 ng/ml. Konsentrasi progesteron $\mathrm{K} 2$ jauh lebih tinggi dibandingkan K1 kemungkinan disebabkan pada K2 hormon GnRH mampu meningkatkan konsentrasi progesteron melalui pembentukan korpus luteum asesoris (Pursley et al., 1995). Pada hari ke-14, konsentrasi progesteron K1 lebih tinggi dibandingkan K2 (7,607 ng/ml dan $4,705 \mathrm{ng} / \mathrm{ml})$. Hal ini dapat terjadi kemungkinan karena pada K2, GnRH hanya dapat meningkatkan konsentrasi progesteron melalui pembentukan korpus luteum asesoris hanya pada fase luteal awal. Setelah pertengahan fase luteal, progesteron akan rendah karena korpus luteum asesoris telah mengalami regresi. Faktor lain yang dapat menyebabkan K1 lebih rendah adalah stres karena penyuntikan berulang yang mengakibatkan konsentrasi progesteron relatif rendah.

Konsentrasi progesteron hari ke-21 pada $\mathrm{K} 1$ lebih tinggi dibandingkan K2 $(5,220 \mathrm{ng} / \mathrm{ml}$ dan $1,797 \mathrm{ng} / \mathrm{ml})$. Hal ini terjadi kemungkinan karena pada K1 terjadi siklus birahi yang lebih singkat. Landasan teorinya sesuai dan penjelasan di bawah menguatkannya) sehingga pada hari ke21 sudah merupakan fase luteal awal. Menurut Toliehere (1985) domba memiliki siklus estrus yang pendek dengan rata-rata 16-17 hari. Afiati dan Herdis (2013) melaporkan bahwa panjang siklus birahi pada domba berkisar 14-19 hari. Variasi panjang siklus akan memengaruhi konsentrasi progesteron jika diukur pada hari ke21.

\section{SIMPULAN}

Simpulan penelitian ini bahwa tidak terdapat perbedaaan konsentrasi progesteron selama siklus birahi pada domba Waringin yang diinduksi birahi dengan kombinasi PGF2 $\alpha$ dan GnRH dibandingkan dengan induksi birahi dengan PGF2 $\alpha$ tunggal.

\section{DAFTAR PUSTAKA}

Afiati, F. dan S. Herdis. 2013. Pembibitan Ternak Dengan Inseminasi Buatan. Penebar Swadaya. Jakarta.

Arimbawa, I.W.P., I.G.N.B. Trilaksana, T.G.O. Pemayun. 2012. Gambaran Hormon Progesteron Sapi Bali Selama Satu Siklus Estrus. Ind. Med. Vet. 1(3):330-336
Blakely, J. dan D.H. Bade. 1998. Ilmu Peternakan. Edisi ke-4. Srigandono, B. (Penterjemah). Gadjah Mada University Press. Yogyakarta.

Bradford, G.E. 1985. Selection for Litter Size. In Genetics of Reproduction in Sheep. Land, R.B. and D.W. Robinson (Eds.). Butterworth, London.

Bradford, G.E., J.F. Quirke, P.Sitorus, I. Inonu, B. Tiesnamurti, F.L. bell, I.C. Fletcher, and D.T. Torrel. 1986. Reproduction in Javanese Sheep: Evidence for a gene with large effect on ovulation rate and litter size. J. Anim. Sci. 63:418-431

Cole, H. H. and B. Cupps. 1969. Reproduction Domestic Animals. 2nd. Academic Press. New York, London.

Efendi, M., T.N. Siregar, Hamdan, Dasrul, C. N. Thasmi, Razali, A. Sayuti, dan B. Panjaitan. 2015. Angka kebuntingan sapi lokal setelah diinduksi dengan protokol ovsynch. J. Ked. Hewan. 9(2): 159-162.

Garcia, M., O. Perera, W.J. Goodger, C. Eisele, A. Fischer, C. Kreutzman, and J. Pelletier. 1996. User Manual for Artificial Insemination Database Application (AIDA), Version 3.3, Animal Production and Health Section. Vienna.Austria. Joint FAO/IAEA Division

Hafez, E.S.E. and B. Hafez. 2000. Reproduction in Farm Animal. $7^{\text {th }}$ ed. Lea and Febiger, Philadelphia.

Jainudeen, M.R. and E.S.E. Hafez. 2000. Pregnancy Diagnosis. In Reproduction in Farm Animals. Hafez, B. and E.S.E. Hafez (Eds.). $7^{\text {th }}$ ed. Lippincott Williams \& Wilkins. Philadelphia.

Manalu, W. dan M. Y. Sumaryadi, and N. Kusumorini. 1994. The Effect of Fetal Number on Maternal Serum Progesteron and Estradiol of Ewes During Pregnancy. Presented in International Seminar on Tropical Animal Production. Yogyakarta, November 7-8, 1994.

Mee, M.O., J.S. Stevenson, B.M. Alexander, dan R.G. Sasser. 1993. Administration of Gnrh at Estrus Influences Pregnancy Rates, Serum Concentrations of LH, FSH, Estradiol-17 Beta, Pregnancy-Specific Protein B, and Progesterone, Proportion of Luteal Cell Types, and In Vitro Production of Progesterone in Dairy Cows. J. Anim. Sci. 71(1):185-198

Neher, G.M. dan M.X. Zarrow. 1954. Concentration of Progestin in The Serum of The Non-Pregnant, Pregnant and PostPartum Ewe. J. Endocrinol. 11: 323-330. 
Partodihardjo, S. 1992. Ilmu Reproduksi Hewan. PT. Mutiara Sumber Widya, Jakarta.

Pursley, J.R., M.O. Mee, and M.C. Wiltbank. 1995. Synchronization of Ovulation in Dairy Cows using PGF2 alpha and GnRH. Theriogenology 44:915-923.

Simões, J. 2016. Synchronization of Ovulation in Goats using Prostaglandin F2 $\alpha$ based Protocols during The Breeding Season. $J$. Coastal Life Medicine. 4(3): 240-243.

Siregar, T.N. 1998. Induksi Ovulasi Kambing Kacang Prapuber dengan PMSG dan HCG. Tesis. Program Pascasarjana. UGM. Yogyakarta.

Siregar, T.N. 2002. Pengukuran profil progesteron sebagai suatu metode diagnosis kebuntingan dini dan kelahiran kembar pada domba lokal. Med. Ked. Hewan. 18(2): 73-77.

Sumaryadi, M.Y. Prayitno, D. Purwantini dan A. Susanto. 2001. Analisis Keragaman Isozim Laktat Dehidrogenase Pada Berbagai Tingkat Prolifikasi Induk Domba Ekor Tipis. Seminar Nasional Teknologi Peternakan dan Veteriner: 5964.

Taponen, J. 2009. Fixed-Time Artificial Insemination in Beef Cattle. Acta Vet. Scand. 51(48): 1-6.

Thorburn, G. D., J.M. Bassett, and I.D. Smith. 1969. Progesterone Concentration in The Peripheral Plasma of Sheep During The Oestrous Cycle. J. Endocrinol. 45: 459469.

Toelihere, M.R. 1985. Fisiologi Reproduksi pada Ternak. Angkasa, Bandung.

Wijono dan B. Didi. 1998. Peran Kadar Progesteron dalam Plasma Darah untuk Deteksi Estrus dan Aktivitas Ovarium. Seminar Nasional Peternakan dan Veteriner 1998: 268-269.

Wubishet, B., D.J. Kesler, C.N. Graves, S.L. Spahr, and R.J. Favero. 1991. Preovulatory LH Profiles of Superovulated Cows and Progesterone Concentrations at Embryo Recovery. Theriogenology 35: 451-457. 